\title{
Gram per Tablet
}

National Cancer Institute

\section{Source}

National Cancer Institute. Gram per Tablet. NCI Thesaurus. Code C73723.

A tablet dosing unit expressed in gram(s) per tablet. 